\title{
The features of the implementation of the sports law Características de la implementación del derecho deportivo
}

*Olena R. Dashkovska, *Olga A. Yavor, *Tetiana I. Brovchenko, *Yevheniia V. Huz, **Olha O. Barabash *Yaroslav Mudryi National Law University (Ukraine), **Lviv Polytechnic National University (Ukraine)

\begin{abstract}
Development of physical culture and sports and updating of a healthy lifestyle lead to increasing of public interest in the sports sector inevitably. It entails the creating of sport's law as a separate branch of law associated with numerous scientific researches, legal practices and professional activities of athletes, sports industry' managers and supporters of a healthy lifestyle. The article is aimed to the theoretical analysis of certain aspects of the legal regulation of sports relations that form a new branch of sports law, determining its place in the national and international legal systems. The comparative legal analysis is the leading scientific approach of this study, which allows to discover the degree of scientific development of this issue with the purpose of increasing the efficiency of legal regulation of physical education and sports. An attempt was made to present sports law as an independent branch of law, resulting from a synthesis of international and national law that regulate relations in different industries through the lenses of public and private law. The specificity of this branch of law leads to a high degree of controversy in the question of determining its features, which are properly investigated in the work. Criteria of the features of the implementation of sports law are formulated: substantive capacity, external borders with other branches of law, national characteristics and international universality.
\end{abstract}

Keywords: sports law, physical education and sports, limits of law, boundaries of sports law, sports legal relations, sports sphere.

Resumen. El desarrollo de la cultura física y el deporte y la renovación de un estilo de vida saludable conducen inevitablemente a un aumento del interés público en el campo deportivo. Esto implica la creación del derecho deportivo como una rama separada del derecho, asociada con numerosas investigaciones científicas, práctica legal y actividades profesionales de atletas, líderes de la industria del deporte y partidarios de un estilo de vida saludable. El artículo tiene como objetivo el análisis teórico de aspectos individuales de la regulación jurídica de las relaciones deportivas, que configuran una nueva rama del derecho deportivo, determinando su lugar en los ordenamientos jurídicos nacionales e internacionales. El análisis jurídico comparado es el enfoque científico principal de este estudio, que permite identificar el grado del desarrollo científico de este tema con el fin de incrementar la efectividad de la regulación legal de la educación física y el deporte. Se hizo un intent de presentar el derecho deportivo como una rama independiente del derecho, que surgió como resultado de la síntesis del derecho internacional y nacional que regula las relaciones en diversas industrias a través del prisma del derecho público y privado. La especificidad de esta rama del derecho genera un alto grado de contradicciones en el tema de determinar sus características, las cuales son debidamente investigadas en el trabajo. Se formulan criterios de las peculiaridades de la implementación del derecho deportivo: capacidad material, fronteras exteriores con otras ramas del derecho, características nacionales y universalidad internacional. Palabras clave: derecho deportivo, cultura física y deporte, límites del derecho, límites del derecho deportivo, relación legal deportiva, esfera del deporte.

\section{Introduction}

The solution to the issues of strengthening the health of citizens, increasing the number of people involved in sports and physical culture, developing high-performance sports is possible only with the creation of an effective regulatory framework. In its development, as practice shows, one should rely only on objective, critical analysis and interpretation of not only national, but also foreign experience, on understanding the development trends of the entire sports sphere and its individual directions. Proceeding from this, the entire regulatory and legal and programmatic and methodological base of sports and physical culture, both in individual countries and the international sports movement as a whole, is being built and then implemented (Solis-Urra et al., 2019).

Since the beginning of the $21^{\text {st }}$ century, the legal systems of many countries have recognized and adopted sports law as a national strategy for the protection of domestic sports and events. In national strategies, states have developed standards governing the functioning of the sports system,

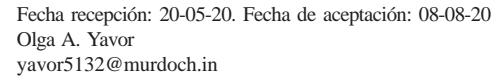

institutions, and sporting events. The role of the state also consists in ensuring and maintaining the social functions of sports. Features of the organization of the sports industry, in turn, put pressure on the law. The specifics of the organization of the sports industry is manifested at the legislative level. Sports law reflects the features of the legal regulation of a complex social relation in the field of physical education and sports, taking into account national strategies and main goals, allowing to understand better and to apply the appropriate legal norm. And for this reason, sports law can be a valuable intellectual and pedagogical tool. Practice shows that the application of the law to sports is not always feasible, and the doctrinal tools are quite contradictory (Lindholm, 2016; Rodríguez-Fernández et al., 2018).

Sports law is one of the newest branches of the legal system, determined by fundamental principles and specific regulatory decisions relating to various areas of law. Sports legislation is the result of combining various segments into a separate system with its own borders, which actualizes research in this direction. Furthermore, the field of sport touches on important social issues such as race and gender, and it also affects the health and culture of the nation and the world community at large. The interaction between sports and law and the mutual influence are two separate areas, 
each of which should be developed individually, ensuring the development of sports law as a separate branch of law.

The legal aspects of the regulation of sports law were studied by such scholars of Western Europe: Casini (Casini, 2011), Loquin (2003), Nafziger(2006), Grayson(2008), Simon (1995), Felops et al. (2006), Foster (2005, 2019), Serdyukov (2010), Bordiuhova (2009) et al. The blurring of the boundaries of sports law is also evidenced by its study in other sciences, namely in administrative law (Dzhafarova \& Ivantsov, 2011): concerning state regulation of the institutions of physical culture and sports management (Bytiak, 2003; Ostapenko et al., 2008), within the framework of the tourist direction (Kivalov, 2004), in the aspect of youth policy (Averyanov, 2005). Nevertheless, the subject matter remains understudied, and its doctrinal interpretation is ambiguous, and therefore this issue requires a comprehensive study that has not yet been conducted and is complicated by the lack of systematization of legal acts regulating relations in the field of sports in Ukraine.

The purpose of the research is to analyse certain aspects of the legal regulation of sports relations that form a new branch of sports law, determining its place in the national and international legal systems.

\section{Materials and methods}

To achieve the purpose, several theoretical research methods were used, both general scientific and special. The analysis methodology lies in the investigation of the main provisions of the legislative framework and the system of sports law, including the development of recommendations for clarifying the object of study. The main research method is a comparative one, which allows comparing the regulation of the object of study in the legal system of Ukraine, other countries, and at the international level. In addition, methods of analysis, synthesis, analogy, analytical, systemic, structural, and classification methods were used.

Structural and functional analysis allowed to identify the levels of analysis of the boundaries of sports law. The descriptive method allowed to present the results of the study in a logical and interconnected form. The study touches upon the method of historical analysis, which allowed to analyse the formation of the field of sports law within the framework of the outlined chronology.

The integrative method allowed for analysis at two levels - regarding the degree of integration of Ukrainian sports law into the international legal framework and into the national legal system. The totality of the used methodological base allowed to ultimately ensure the reliability and validity of the findings. Based on the identified patterns and gaps in legal regulation, a conclusion is drawn on the main directions of improving the legislative framework for the development of sports law and the regulatory aspects of determining its boundaries, including in Ukraine.

\section{Results and Discussion}

Sports law is defined differently in special legal literature:

1) independent branch of law (Egorichev, 2006);

2) integrated branch of law (Bordiuhova, 2009;

Amirov, 2005; Karthik, 2019) or legislation (Serdyukov, 2010);
3) legal institution (Duval, 2018).

In our opinion, the most correct is the first opinion, because sports law in Ukraine is gradually acquiring the features of an independent branch of law, forming legal relations that are specific in nature and content, uniting the institutions of sports refereeing, arbitration, responsibility, competitions, Olympic, youth sports, etc. Regarding this issue, H.Yu. Bordiuhova (2009) notes that as a separate branch of national law, sports law is at the stage of development, forming its complexity by compiling elements of other branches of law, while the branch of international sports law has long been formed.

The blurring of the boundaries of sports law is facilitated by legal uncertainty regarding the definition of the role and place of this industry in the legal system. In particular, in the Constitution of Ukraine, the provision on the development of physical culture and sports is enshrined in the article on regulation of the rights to healthcare, medical care, and medical insurance, that is, among social rights, not cultural ones. The legislation on culture, in particular law No. 2778 (The Law of Ukraine No. 2778-VI..., 2010), also does not contain provisions on physical education and sport as part of national culture.

Accordingly, in the national legal framework, the branch of physical education and sports is included in both the social and cultural fields. Furthermore, it is intricately connected with other areas, for example, economic, which regulates various forms of financial and economic activities in the field of sports and physical education. These aspects suggest the specialization of law and legislation in the researched area, which objectively gives reason to consider sports law as a complex branch of law.

The system of sports legal relations, which are the subject of regulation of sports law, should include a certain relatively homogeneous set of social relations that arise in connection with the implementation of certain organizational, social, economic, and other aspects of activities in the field of sports and physical education, which are closely related to the exercise of rights and human interests in the relevant field, including social relations that arise upon creating conditions for the development of sports and physical education and, furthermore, the associated economic, administrative, property, civil, labour, and financial public relations, which arise in connection with the organization and implementation of targeted measures concerning sports (Aparov, 2018).

In the process of development of sports law there is an objective need for regulation and streamlining of sports relations by authorized public authorities. The growing dynamics of standard-setting activities in sports relations and doctrinal substantiation of the specifics of the subject sports law created a theoretical foundation and determined the basis of the vector further development of sports law of Ukraine as a separate integrated industry in legal system of Ukraine. Today we can talk about the formation subject of regulation of sports law, despite its relative novelty in legal science, with its inherent signs of complexity and relative independence. This conclusion on the scope of sports law as a legal phenomenon is justified by the following factors:

1) sports law includes its own sectoral legal structures and mechanisms that are not inherent in other 
legal branches and spheres of public life, but at the same time has a complex of provisions;

2) sports law combines private and public elements, private law and public law means and regulatory mechanisms;

3) sports law has a special legal regime, its subject and methods of regulation, principles, and other industry characteristics.

The complexity of the sports law industry is also conditioned upon the fact that the industry is regulated, apart from the legislative national standards, by international regulations and corporate standards. These aspects outline the boundaries of the substantial scope of sports law as an integral element of the legal system of local, national, and international (interethnic) levels.

In this dimension, sports law, apart from the statutory content, also includes other elements regulated at the legal level (sports legal culture, sports legal ideology, institutions in the field of sports law, practice of sports disputes, etc.). At the same time, the most common statutory approach in legal science is when the substantive limits of sports law are limited by the system of legal provisions governing relations in the field of sports (Alekseev, 2016). Currently, there is a multitude of regulations governing sports, published at the international, state, and municipal levels, as well as local government law-making and corporate statutory activity delegated by the state.

The boundaries of sports law at the national level are determined by the existing regulatory framework and its regulation by the provisions of both private and public law. Despite the fact that the Constitution of Ukraine does not directly regulate sports relations, it is the foundation for the development of specialized legislation in the field of sports.

The main piece of legislation is the special law «On Physical Education and Sports» (The Law of Ukraine No. 3808-XII..., 1993), which contains the legal, organizational, social, and economic foundations of activities in the field of physical education and sports and a mechanism for regulating their development in the country. This area is also governed by such laws of Ukraine as «On Supporting the Olympic, Paralympic Movement, and Sports of Higher Achievements in Ukraine» (Law of Ukraine No. 1954..., 2000), «On Anti-Doping Control in Sport» (The Law of Ukraine No. 1835...,2017).

A few substatutory acts should also be mentioned: Decrees of the President of Ukraine «On the National Doctrine of the Development of Physical Education and Sports» (Decree of the President of Ukraine No. 1148..., 2004), «On the National Strategy for Health-Improving Physical Activity in Ukraine for the Period until 2025» (Decree of the President of Ukraine No. 42..., 2016). Decree of the President «On the National Strategy for Health-Improving Physical Activity in Ukraine for the period up to 2025 «Physical activity - a healthy lifestyle - a healthy nation» (Decree of the President No. 42/2016..., 2016); Resolution of the Cabinet of Ministers of Ukraine on the implementation of the strategy for recreational physical activity (Resolution of the Cabinet of Ministers No. 666-p..., 2019); Decisions of the Cabinet of Ministers of Ukraine «On the Promotion of Athletes and Coaches in Olympic and Non-Olympic Sports» (Resolution of the Cabinet of Ministers of Ukraine No. 91..., 2016); «On approval of the Regulation on the Centre of Olympic Training» (Resolution of the Cabinet of Ministers of Ukraine No.948..., 2011).

A considerable amount of legal regulation was issued by the Ministry of Youth and Sports of Ukraine, in particular with regard to the holding of Ukrainian championships in various sports, the procedure for awarding athletes and coaches with sports titles and categories in various sports, the rating of Olympic sports in Ukraine, etc. According to S.V. Alekseev (2016), international sports law includes provisions of international law and national legislation.

At the international level, the following documents should be noted: The International Charter of Physical Education and Sport (1978) - enshrines the right of everyone to develop physical, intellectual, aesthetic, and other abilities through physical education and sports, which should be guaranteed by states as an inalienable right The program of cooperation in the field of education, culture, youth and sports between the Cabinet of Ministers of Ukraine and the Government of the State of Israel for 2019-2022, 2019); The International Convention against Apartheid in Sports, the International Convention against Doping in Sports, the Nairobi Treaty for the Protection of the Olympic Symbol, the European Convention on Violence and Unlawful Behaviour by Spectators during Sporting Events and, in particular, Football Matches (1985); and others, including bilateral agreements (for example, the Cooperation Program with the State of Israel for 2019-2022) (The program of cooperation in the field of..., 2019).

In 2007, the Inter-Parliamentary Assembly of the CIS Member States approved a model law on professional sports (Resolution of the Interparliamentary Assembly of the CIS Member States..., 2007). One of the leading sources of international law governing private international sports relations are acts of international sports organizations (charters, regulations, etc.). The basic principles, provisions, and rules of the functioning of the Olympic movement, the activities of the International Olympic Committee, international federations in sports, national Olympic committees, organization and holding of the Olympic Games are concentrated in the Olympic Charter of the International Olympic Committee.

Incomplete regulation of sports relations at the national and departmental levels leads to the objective need for their settlement at the corporate level and increase in the number of corporate acts (the so-called «soft law»). S.A. Yurlov (2018) characterizes this phenomenon as «the boundaries and limits of state regulation and self-regulation in the field of physical education and sports» (Yurlov, 2018). According to V. Vaskevich (2015), corporate and local acts of sports organizations today actually form the basis of legal regulation of relations in the field of professional sports, sports of the highest achievements, including children's and youth sports (Rogachev, 2018). The current situation gives reason to recognize these acts as an independent element of national sports legislation.

However, the regulations currently in force in the field of physical culture of sports do not cope with the task of effectively regulating these legal relations, which requires the improvement and reform of sports legislation and the 
adoption of highly specialized legislative acts, for example, laws such as «On Professional Sports» and «On Children and Youth sport «, and in the future, the codification of a significant array of regulatory legal acts. Relations in this area could be regulated by the development and adoption of the Sports Code.

The boundaries of the sports law can also be identified within it. This primarily refers to the delineation of sports legal relations directly in the field of sports and fields related to it. However, this classification of internal borders is within the framework of the subject of legal regulation of the branch of sports law. Classification into sports within internal boundaries is also appropriate here, of which there are much more in this branch of law, unlike other branches.

The external boundaries of sports law separate it from other legal industries. Apart from the direct sports provisions, sports relations are governed by a few regulatory and social provisions of other branches of law, in particular, we previously mentioned the significant reflection of sports law in the administrative law. Subject delineation of sports law is also possible, for example, with relations in the field of sports training - the provisions of educational and pedagogical law, in the field of healthcare - with the field of healthcare in medical law. Thus, sports law adjoins, and in some matters intersects with administrative, labour, medical, social, civil, and other types of law.

On the basis of external borders, sports law as well as other branches of national law is delimited by the international (supranational (Liutkute, 2019)) level of implementation. J. Nafziger (2006) on the basis of conclusions about the globalization of sports competitions predicts the expansion of the sports sector of international law and the increasing role supranational treaty) (Nafziger, 2006). With regard to this position, it is worth noting the presence of a certain discussion. In particular, K. Foster (2005) suggests distinguishing between the categories of international («principles of international law applicable to sport») and global («transnational autonomous legal order created by private global sports institutions that regulate international sports»). In its most general form, international sports law is a system of interrelated norms and rules governing social relations that develop in international sports activities.

\section{Conclusions}

Thus, the study identified four criteria for determining the boundaries of the implementation of sports law: substantial content, external borders with other branches of law, internal delimitation and international character. As a relatively new sphere, sports law has a number of challenges in the process of formation, which determines the further dynamic development of existing ones, as well as the creation of new legal structures and mechanisms to regulate sports relations. Existing national legislation is outdated in certain provisions, not meets the needs of the modern development of national physical culture and sports. Improving the legislative framework of sports law, bringing its standards to modern standards of regulation of professional sports and propaganda physical education is one of the priority areas of state policies.
The development of professional sports requires the adoption at the national level of a separate legislative act that clearly defines the basic principles and norms of a legal regulation of sports relations, given the complex nature of sports rights, a tendency to go beyond national legal boundaries. Study shows the appropriateness of sports law as a separate branch of Ukrainian law, which enhances the relevance and need for further research to explain the boundaries of the implementation of sports law.

\section{References}

Alekseev, S.V. (2016). Sports law. Moscow: UNITY-DANA: Zakon \& Pravo.

Amirov, I.M. (2005). Legal regulation of sports-technical relations. Krasnodar: Krasnodar Academy of the Ministry of Internal Affairs of Russia.

Aparov, A.N. (2018). Sports subjective law in the system of national law and sports relations. Dictum Factum, 1, 34 43.

Averyanov, V.B.(Ed.) (2005). Administrative Law of Ukraine. Kyiv: Yurydychna Dumka.

Bordiuhova, H.Yu. (2009). International Sports Law as a Basis for Formation of the National Law Branch «Sports Law of Ukraine». Mariupol: Mariupol State Humanities University.

Bytiak, Yu.P. (Ed.). (2003). Administrative law of Ukraine. Kharkiv: Pravo.

Casini, L. (2011). The Making of a Lex Sportiva by the Court of Arbitration for Sport. German Law Journal, 12(5-6), 1317-1340.

Decree of the President No. 42/2016 «On the National Strategy for Improving Pshysical Activity in Ukraine for the period until 2025 «Physical activity - a healthy lifestyle - a healthy nation». (2016). Bushfire resources: Liga zakon. Retrieved from http://search.ligazakon.ua/ 1_doc2.nsf/link1/info/U042_16.html

Decree of the President of Ukraine No. 1148 «On the National Doctrine of the Development of Physical Culture and Sports». (2004). Bushfire resources: Zakon Rada. Retrieved from https://zakon.rada.gov.ua/laws/show/ 1148/2004

Decree of the President of Ukraine No. 42 «On the National Strategy for Health-Improving Physical Activity in Ukraine for the Period until 2025». (2016). Bushfire resources: Liga zakon. Retrieved from https://cutt.ly/ HsMDQoL

Duval, A. (2018). The Olympic Charter: A Transnational Constitution Without a State? Journal of Law and Society, 45(1), 245-269.

Dzhafarova, O.V., \& Ivantsov, V.O. (2011). Sports law as a sub-branch of the Special part of administrative law. Yuryst Ukrainy, 3 (16), 44-49.

Egorichev, A.N. (2006). Constitutional and legal foundations of physical education: Russian and foreign experience. Moscow: M.V. Lomonosov Moscow State University.

Felops, W., Morali, A., Sell, D., Mikhailov, E., Gortsunyan, S., \& Klyachin A. (2006). Sport as an object of legal regulation in the UK. Sport: Economics, Law, Management, 3, 916. 
Foster, K. (2005). Lex Sportiva and Lex Ludica: the Court Of Arbitration for Sport's Jurisprudence. Entertainment and Sports Law Journal, 3, 1-15.

Foster, K. (2019). Global Sports Law Revisited. The Entertainment and Sports Law Journal, 17(1), 4.

Grayson, E. (2008). Barrister and specialist on sport and the law. Retrieved from http://www.timesonline.co.uk/tol/ comment/obituaries/article4855567.

International Charter of Physical Education and Sport. (1978). Bushfire resources: Zakon Rada. Retrieved from https:/ /zakon.rada.gov.ua/laws/show/995_350

Karthik, R. (2019). Importance of Sports Law by Advocate. Retrieved from https://www.lawyered.in/legal-disrupt/ articles/importance-sports-law-advocate-karthikraghavan

Kivalov, S.V. (Ed.). (2004). Administrative law. Kharkiv: Odyssei.

Law of Ukraine No. 1954 «On Support of the Olympic, Paralympic Movement and Sports of Higher Achievements in Ukraine». (2000). Bushfire resources: Liga zakon. Retrieved from https://cutt.ly/bsMAgvL

Lindholm, J. (2016). The Second Annual International. International Sports Law Journal 16(3-4), 129-130.

Liutkute, G. (2019). What sports law tells you about transnational law. Retrieved from https:/cutt.ly/ 1sMKAm9

Loquin, E. (2003). L’internationalisation des contrats sportifs. In: L'exemple du football professionnel (pp. 33-45). Paris: PUF.

Nafziger, J.A.R. (2006). Lex Sportiva and CAS. In: The Court of arbitration for sport (pp. 1984-2004). Hague: TMC Asser Press.

Ostapenko, O.I., Kysil, Z.R., Kovaliv, M.V., \& Kysil, R.V.(2008). Administrative Law. Kyiv: All-Ukrainian Publishers Association «Pravova Yednist».

Resolution of the Cabinet of Ministers No. 666-p «On approval of a plan of measures for the implementation of the National strategy for improving physical activity in Ukraine for the period until 2025 «Physical activity - a healthy lifestyle - a healthy nation» for 2020". (2019). Bushfire resources: Liga zakon. Retrieved from http:// search.ligazakon.ua/1_doc2.nsf/link1/KR190666.html

Resolution of the Cabinet of Ministers of Ukraine No. 91 «On the Promotion of Athletes and Trainers in Olympic and Non-Olympic Sports». (2016). Bushfire resources: DATABASE LEGISLATION OF THE CIS COUNTRIES. Retrieved from http://base.spinform.ru/ show_doc.fwx?rgn=86820

Resolution of the Cabinet of Ministers of Ukraine No. 948 «On Approval of the Regulation on the Olympic Training Centre». (2011). Bushfire resources: online.zakon.kz. Retrieved from https://cutt.ly/5sMHtPM

Resolution of the Interparliamentary Assembly of the CIS Member States «Model Law on Professional Sports» No. 28-8. (2007). Bushfire resources: Zakon Rada. Retrieved from https://zakon.rada.gov.ua/laws/show/ 997_g25

Rodríguez-Fernández, J.E., Abelairas-Gómez, C., \& PeixotoPino, L. (2018). Analysis of the use of the old gymnastic and athletics material of the general law on education in present physical education classes. Retos, 34, 300-304.

Rogachev, D.I.(Ed.). (2018). Sports law of Russia: a textbook for masters. Moscow: Prospect.

Serdyukov, A.V. (2010). Sports law as a complex branch of legislation. Moscow: Nauka.

Simon, G. (1995). L'arbitrage des conflits sportifs. In: Revue de l'arbitrage (pp. 185-209). Paris: Librairie Générale de Droit et de Jurisprudence.

Solis-Urra, P., Fernández-Cueto, N., Nanjarí, R., Huber-Pérez, T., Cid-Arnes, M. P., Zurita-Corvalán, N., RodriguezRodriguez, F., \& Cristi-Montero, C. (2019). Better Fitness, Better Results of a Law Against Obesity. Retos, 36, 1721.

The Law of Ukraine No. 1835 «On Anti-Doping Control in Sport». (2017). Bushfire resources: Zakon Rada. Retrieved from https://cutt.ly/VsMA8fa

The Law of Ukraine No. 2778-VI «On Culture». (2010). Bushfire resources: Liga zakon. Retrieved from http:// search.ligazakon.ua/__doc2.nsf/link1/T102778.html

The Law of Ukraine No. 3808-XII «On Physical Education and Sports». (1993). Bushfire resources: Liga zakon. Retrieved from https://cutt.ly/EsMPKp2

The program of cooperation in the field of education, culture, youth and sports between the Cabinet of Ministers of Ukraine and the Government of the State of Israel for 2019-2022. (2019). Bushfire resources: atr.ua. Retrieved from https://atr.ua/news/189938-ukraina-i-izrail-podpisalirad-dvustoronnih-dogovorov

Vaskevich, V.P. 2015. On the question of the place of sports law in the system of branches of domestic law. Moscow: O.E. Kutafin Moscow State Law University.

Yurlov, S.A. (2018). The development of legal science in terms of research on issues related to the statutory regulation of sports. Bulletin of St. Petersburg University, 9(4), 620-639.

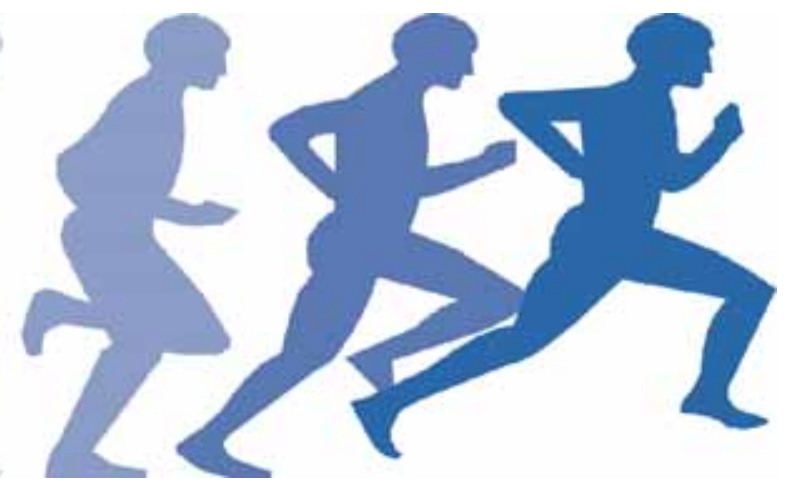

